\title{
The Effect of Cooperative Learning Approach Application Toward Students' Learning Outcome
}

\begin{abstract}
Aly Imron ${ }^{1 *}$
${ }^{1}$ State Polytechnic of Malang

"Corresponding author mralyimron@yahoo.com

ABSTRACT

The recording teaching learning process showed that students tended to be passive because of the inappropriate teaching method so that it affected activity and motivation to perform his skill in their language actively in the class. Choosing method to rise the students' activity is a must. It dealt with students'learning outcome and students' activity outcome as well as an effort to create students more understand to the material given. The objective of the research was to know the differences of an effect between class using jigsaw and NHT method towards cognitive learning outcome. Cooperative learning method is one of the choices that can be used in the classroom because there is a benefit to activate and persuade students to work cooperatively naming Jigsaw dan Numbered Head Together (NHT).The observation result of cognitive domain showed that NHT teaching method indicated higher percentage result than jigsaw teaching method in the cooperative field of the group discussion. In addition, responsibility, activity and willing element had higher percentage outcome than NHT teaching method. Based on Comparative result of Jigsaw and NHT average post-test value of cooperative teaching to the class given JIGSAW method was 8,889. Meanwhile, the class given NHT method was 7,702. It can be said that the class given JIGSAW method was higher average than class given NHT method. Big difference of both averages was 8,889. It showed that JIGSAW method was good to increase student cooperative teaching
\end{abstract}

Keywords: Jigsaw, NHT, cognitive

\section{INTRODUCTION}

In teaching learning process, teacher should browse the appropriate method in line with the progress of the world need. It always changes from time to time. However, it also follows situation and condition of the world itself where the students are. The approaprite methods can be taken by experience when someone is teaching or finding the references from some books. It deals with enriching the world knowledge in teaching in order to maximize students' learning outcome.

To the best of the resercher observation, the outcome of the students of the English language is still lower for some students. This information was gained during teaching using speech method or demonstration that do not contribute to the sufficient result so that it needs the methods' modification. In certain time method is good, but another time it needs some revolution. Therefore, attention to this

\section{METHOD}

Research Design used was experimental method. It is used to know the different result of electrical students using problem must be conducted to overcome the lower score result based on institution qualification score. The following is some factors affecting the student lower score:

1. The presence of prior knowledge test was neglected, so that it is hard to know the studnt competence in English. Giving pre-test is a must before discussing a new topic or chapter.

2. Monotonous method tends to be passive and uninteresting for students.

3. In adequate use of teaching media lack of maximum motivation for learning

The objective of the research is to know:

The difference effect between jigsaw and number head together towards (NHT) towards cognitive learners outcome of technical English.

Numbered Head Together and Jigsaw learning to the English subject.

Shortly, the research design can be seen in Table 3.1 
Table 3.1 Research Design

\begin{tabular}{clcl}
\hline Group & Pretest & Treatment & Postest \\
\hline XI D4 2A & $Y_{1}$ & $X_{1}$ & $Y_{3}$ \\
\hline XI D42 B & $Y_{2}$ & $X_{2}$ & $Y_{4}$ \\
\hline
\end{tabular}

Note: $\quad \mathrm{X} 1=$ Treatment 1 (Jigsaw learning)

$\mathrm{X} 2=$ Treatment 2 (NHT learning)

$\mathrm{Y} 1=$ Pretest score Treatment 1

Y2 $=$ Pretest Treatment 2

Y3 $=$ Postest Treatment 1

Y4 $=$ Postest Treatment 2

The research is conducted in electrical study program, state polytechnic of Malang november 2018 using cooperative teaching as free variable, jigsaw and Numbered Head Together (NHT) as two dimensional approaches. Learning outcome is as bound variable which has cognitive dimension.

Population was 48 electrical students and sample was $\mathrm{d} 4$ $2 \mathrm{~A}$ using jigsaw. Meanwhile d42B was using NHT. The instrument used was students' learning outcome before and after given treatment.

Test is an intrument used to measure students 'learning outcome. The total objective test was 10 items. Every student was given 30 minutes to answer all question. If the students answered truly, 1 item was scored 1 and if it was wrong scored 0 .

Before used as research instrument, it was tried out in the second year students of the same study program. The try out of instrument test was used to examine validity (v), reliability (r), which was calculated using SPSS for windows.

\section{a. Item Validity}

Validity is a measurement indicating validity level of instrument. Valid instrumen has high coefisient validity. Otherwise, unvalid instrumen validity has low coefisient validity. Test is valid if it measures what it should measure. (Arikunto, 2003:65). Scoring used SPSS for windows

Test of item validity was used to know apropriate level of each test item meaning that the item test should measure what it really measures. The subject of this was D3 students. The criteria of test is valid if $r$ count $>r$ table (Arikunto, 2002:75).Test result of item validity can be seen in table 3.2

Table 3.2 Test Result of Item Validity

\begin{tabular}{|c|c|c|c|}
\hline $\begin{array}{c}\text { Test } \\
\text { number }\end{array}$ & rcount & rtable & Notes \\
\hline 1 & 0.518 & 0.404 & Valid \\
\hline 2 & 0.435 & 0.404 & Valid \\
\hline 3 & 0.428 & 0.404 & Valid \\
\hline 4 & 0.669 & 0.404 & Valid \\
\hline 5 & 0.537 & 0.404 & Valid \\
\hline 6 & 0.647 & 0.404 & Valid \\
\hline 7 & 0.631 & 0.404 & Valid \\
\hline 8 & 0.535 & 0.404 & Valid \\
\hline 9 & 0.505 & 0.404 & Valid \\
\hline 10 & 0.518 & 0.404 & Valid \\
\hline
\end{tabular}

Based on table 3.2 above can be concluded that all test items was valid so that no items was changed or deleted.

\section{b. Test Reliability}

According to Arikunto (2002:59-60), reliability deals with trustworthiness. Test can be considered has high trustworthiness if it can give fixed score, meaning that if something happens permanently, the high permanent can show the high reliabily instrument. Test reability is done using alpha score, if the alpha score is higher than $r$ table, $r$ is called reliable, but if it is lower than $r$ table, the test is called unreliable.

To examine the reliability, it is used Reliability Analysis Scale Alpha with SPSS program for window. 
Reliability shows that instrument is adequate to be used as data collector because the instrument has been correct. Reliability examination was done by reading alpha score. If alpha coefisien value is approximately 1 score, the instrument has high reliability. However, it is unreliable, if it has low reability. (Sukardi, 2004:128). The following is the result of test instrument reliability.

Table 3.3 The result of test instrument reliability.

Case Processing Summary

\begin{tabular}{|ll|r|rr|}
\hline & & $\mathrm{N}$ & \multicolumn{1}{c|}{} \\
\hline Cases & Valid & 24 & & 100.0 \\
& Excluded $^{\mathrm{a}}$ & 0 & .0 \\
& Total & 24 & & 100.0 \\
\hline
\end{tabular}

a. Listwise deletion based on all variables in the procedure.

Reliability Statistics

\begin{tabular}{|r|c|}
\hline Cronbach's Alpha & N of Items \\
\hline .722 & 10 \\
\hline
\end{tabular}

Item-Total Statistics

\begin{tabular}{|c|r|r|r|r|}
\hline & $\begin{array}{c}\text { Scale Mean if } \\
\text { Item Deleted }\end{array}$ & $\begin{array}{c}\text { Scale } \\
\text { Variance if } \\
\text { Item Deleted }\end{array}$ & $\begin{array}{c}\text { Corrected } \\
\text { Item-Total } \\
\text { Correlation }\end{array}$ & $\begin{array}{c}\text { Cronbach's Alpha if } \\
\text { Item Deleted }\end{array}$ \\
\hline item_1 & 6.58 & 4.254 & .328 & .712 \\
item_2 & 6.33 & 4.580 & .285 & .715 \\
item_3 & 6.25 & 4.717 & .319 & .711 \\
item_4 & 6.63 & 3.897 & .514 & .676 \\
item_5 & 6.29 & 4.476 & .418 & .697 \\
item_6 & 6.50 & 4.000 & .497 & .680 \\
item_7 & 6.25 & 4.457 & .547 & .687 \\
item_8 & 6.33 & 4.406 & .399 & .698 \\
item_9 & 6.75 & 4.283 & .313 & .715 \\
item_10 & 6.58 & 4.254 & .328 & .712 \\
\hline
\end{tabular}

The table above showed that the Alpha Cronbach value was 0.722 with 10 question items. Value number is approximately 1. Therefore, it is called reliable.

\section{c. Observation}

Observation conducted by the researcher using the aid of observation sheet.

\section{d. Data Analysis}

Data collected was taken from preliminary, final data and observation sheet. After the data collected, it was analyzed with the following procedure. The research question was stated to know cognitive outcome, so it was done by

a. Normality test: to know whether the data distribution is normal or not. SPSS program can detect normality test. The guidance to take Normality test is as follows (Santoso, 2004):

- $\quad$ Significant value or probability value $<0,05$; distribution is abnormal.

- $\quad$ Significant value or probability value $>0,05$; distribution is normal. 
b. Hypothesis test

c. Hypothesis test uses Two Way Anova analysis with SPSS for windows. Hypothesis test is:

- If $\mathrm{t}$-Test is smaller than t-Table so Ho (null Hypothesis ) is accepted, meaning that there is no difference between Jigsaw and NHT method. $\mathrm{H} 1$ is rejected, meaning that there is difference between Jigsaw and NHT method. Ho is accepted if t test $<\mathrm{t}$ table

- If t-Test is bigger than t-Table so Ho (null Hypothesis) is rejected, meaning that there is difference in student outcome between Jigsaw and NHT method. H1 is accepted, meaning that there is no difference between Jigsaw and NHT method. Ho is rejected if $t$ test $>t$ table

\section{FINDINGS AND DISCUSSION}

The research used cooperative learning variable to test whether there is an effect learning strategy using Jigsaw and NHT method. By controlling pretest variable is expected dependant variable/post test score is only influenced by free variable on Jigsaw and NHT learning methods. The technique analysis used was Analysis of Covariance (ANCOVA) which ANCOVA is a method combining between ANOVA and Regression technique described in comparative and correlation. Before discussing result of ANCOVA test it will be presented result of descriptive statistic calculation on three purpose of dependant variable.

\section{Descriptive Statistic}

Summary of descriptive statistic of each variable will be described minimum, maximum, average and deviation standard score to the class given Jigsaw and NHT method at the time given pre-test and post-test. The result is presented in Table 4.1.

Table 4.1 Descriptive Statistic Cooperative Learning Variable

\begin{tabular}{clcccc}
\hline Variable & Score & \multicolumn{2}{c}{ Jigsaw } & \multicolumn{2}{c}{ NHT } \\
\cline { 3 - 6 } & & $\begin{array}{c}\text { Pre- } \\
\text { Test }\end{array}$ & $\begin{array}{c}\text { Post- } \\
\text { Test }\end{array}$ & $\begin{array}{c}\text { Pre- } \\
\text { Test }\end{array}$ & $\begin{array}{c}\text { Post- } \\
\text { Test }\end{array}$ \\
\hline Cooperative & Minimum & 2 & 6 & 4 & 6 \\
Learning & Maximum & 10 & 10 & 9 & 9 \\
& Average & 7 & 8.9 & 6,818 & 7,6 \\
& deviation & 2,41 & 1,23 & 7,681 & 1,08 \\
& Standard & & & & \\
\hline
\end{tabular}

Table 4.1 showed that cooperative learning variable was taken from pre-test average score and Jigsaw and NHT post-test method is not far difference. Meanwhile, the second post-test score, both methods increased, but Jigsaw method score is higher, that is, 8.9. If it is seen descriptively, method before given jigsaw method has average score in line with NHT method.

\section{ANCOVA TEST}

Some requirements that must be fulfilled while using control variable (covariate) is normality, homogeneity, linier correlation between covariate variable (pre-test) with dependant variable (post-test), homogeneity slope regression, independent covariate variable (pre-test) with a treatment (method).

\section{Normality Test}

To know whether pre-test and post-test data of JIGSAW and NHT methods on cooperative learning variable in normal distribution was tested by Kolmogorov-Smirnov test.

Table 4.2. Summary of normality test using Kolmogorov-Smirnov

\begin{tabular}{lcccc}
\hline Variable & Method & Variable & $\begin{array}{c}\text { Sig Kolmogorov- } \\
\text { Smirnov }\end{array}$ & Notes \\
\hline Cooperative & JIGSAW & Pre-Test & 0,624 & Normal \\
learning & & Pos-Test & 0,087 & Normal \\
\cline { 2 - 5 } & NHT & Pre-Test & 0,763 & Normal \\
& & Pos-Test & 0,176 & Normal \\
\hline
\end{tabular}


Based on table 4.2 can be seen that each variable on JIGSAW and NHT methods has value number sig KolmogorovSmirnov pre- test and post-test $>0,05$ so that normality condition has been fulfilled.

\section{Homogeneity variance test}

Homogeneity test is used to know whether data on

JIGSAW and NHT methods have variance homogeneous ability. The method used is Levene's Test of Equality of Errors Variances. Summary of test result of homogeneous variance on each variable as follows:

Tabel 4.3. Summary of Homogeneous Variance Test Using Levene's Test

\begin{tabular}{ccc}
\hline Variable & Sig Levene's Test & Note \\
\hline Cooperative learning & 0,779 & $\begin{array}{c}\text { Homogeneous } \\
\text { variance }\end{array}$ \\
\hline
\end{tabular}

Table 4.3 can be concluded that the three dependant variable, Cooperative learning, has value number sig Levene's Test $>$ 0,05 indicating that variance in that variable is homogeneous.

\section{Linier correlation Condition}

Since ANCOVA involves control variable (covariate), so covariate variable can be seen from linier correlation with dependant variable. To know whether there is linier correlation or not can be seen from the significant value of covariate variable (pre-test) with an output
ANCOVA. If the sig $<0,05$, it means that there is linier correlation between covariate variable (pre-test) with dependant (post-test). Research only one variable that will be precondition beside normality and homogeneity of cooperative learning. Result of linier correlation is shown in table 4.4 .

Table 4.4. Summary of Linier correlation Test of Covariate Variable with Dependant Variable

\begin{tabular}{|c|c|c|c|}
\hline $\begin{array}{l}\text { Dependant } \\
\text { Variable }\end{array}$ & Covariate Variable & $\begin{array}{c}\text { Sig Covariate Variable } \\
\text { toward dependant } \\
\text { Variable } \\
\end{array}$ & Note \\
\hline $\begin{array}{l}\text { Post-Test } \\
\text { Cooperative } \\
\text { Learning }\end{array}$ & $\begin{array}{c}\text { Pre-Test Cooperative } \\
\text { Learning }\end{array}$ & 0,020 & $\begin{array}{c}\text { There is linier } \\
\text { correlation }\end{array}$ \\
\hline
\end{tabular}

Table 4.4. showed that the linier correlation on covariate variable pre-test towards dependant variable post-test of cooperative learning has been fulfilled with sig $<0,05$. It means pre-test variable is appropriate for control variable (covariate).

\section{DISCUSSION}

\section{Cognitive Learning Outcome of Jigsaw and} NHT Cooperative Teaching Method

Based on statistic test result that data showed clearly that there is an effect of cooperative learning approach application towards students learning outcomes of English languages.

From descriptive statistic analysis can be taken that average score of pre-test and post-test of Jigsaw and NHT method is not far different. Meanwhile, in post-test, both methods increased. However, Jigsaw method has average higher score, 8.9. If it is seen from descriptive statistic before given jigsaw method has average score before given NHT method. Actually one method does not change the paradigm of someone learning style. It can happen one method edify the previous attitude although it is tried with another method. It can takes place for another cases.
Based on (1) Normality test using Kolmogorov-Smirnov test showed that each variable on JIGSAW and NHT methods had sig Kolmogorov-Smirnov pre- test and post-test > 0,05 so normality condition has been fulfilled. (2) homogeneity test is used to know whether data on JIGSAW and NHT methods has homogeneous ability variance using Levene's Test of Equality of Errors Variances method having sig Levene's Test $>0,05$ showing that variance on the variable was homogenous (3) Linier correlation condition involving control variable (covariate). Besides that to know whether there is correlation or not by seeing significance covariate variable (pre-test) with output ANCOVA with criteria if sig $<0,05$, it showed that there is linier correlation between covariate variable (pre-test) with dependant (post-test). This research only uses 1 variable to be tested that is comparative teaching method. Result of summary condition of linier correlation is presented in table 4.4. showing that condition 
linier relationship on covariate variable pre-test toward dependant variable post-test of comparative teaching method has been fulfilled with value sig $<0,05$. Therefore, pre-test variable is appropriate used as control variable. (4) Homogeneity variance of slope regression condition of ANCOVA used to test whether slope regression variance had homogenous variance by knowing no interaction between free variable (method) with covariate variable (pre-test) if sig interaction $>0,05$ in table 4.5 stated no interaction to each free variable.

Table 4.5. Summary of variance Homogeneity Slope Regression

\begin{tabular}{cccc}
\hline $\begin{array}{c}\text { covariate } \\
\text { variable }\end{array}$ & Free Variable & Sig Interaction & Notes \\
\hline $\begin{array}{c}\text { Pre-Test } \\
\text { cooperative } \\
\text { teaching }\end{array}$ & Method & 0,592 & $\begin{array}{c}\text { No interaction/ slope } \\
\text { homogeny }\end{array}$ \\
\hline
\end{tabular}

Method with covariate variable Post-Test of cooperative teaching with value sig was 0,592. Therefore, pre-test condition as covariate variable was also fulfilled. (5) Free covariate variable condition with free variable shown with correlation test result stating that there is no correlation meaning that both variable had no relationship as stated in table 4.6 that sig correlation each was 0,574 meaning that there is no correlation between

Table 4.6. Summary of variance Homogeneity test of Slope Regression

\begin{tabular}{cccc}
\hline $\begin{array}{c}\text { Covariate } \\
\text { Variable }\end{array}$ & Free variable & Sig correlation & Notes \\
\hline $\begin{array}{c}\text { Pre-Test } \\
\text { cooperative } \\
\text { teaching }\end{array}$ & Method & 0,574 & Free to each other \\
\hline
\end{tabular}

covariate variable with free variable. All precondition of ANCOVA was fulfilled so that it can be described further how the effect of JIGSAW and NHT learning method towards cooperative learning by controlling pre-test variable.

Next, hypothesis test of effect of learning method towards cooperative learning score. Hypothesis used is the effect of teaching method towards cooperative learning as follows:
$\mathrm{HO}$ : there is no effect of learning method towards cooperative teaching by controlling pre-test variable.

$\mathrm{H} 1$ : there is effect learning method towards cooperative teaching by controlling pre-test variable.

Alternative Hypothesis (H1) will be accepted if sig value < 0,05 .

Table 4.7. Summary of ANCOVA

\begin{tabular}{cccccc}
\hline SK & JK & db & KT & F & Sig. \\
\hline Method & 15,477 & 1 & 15,477 & 13,010 & 0,001 \\
$\begin{array}{c}\text { Pre-cooperative } \\
\text { teaching }\end{array}$ & 7,818 & 1 & 7,818 & 6,572 & 0,014 \\
Error & 3101,000 & 41 & 1,190 & & \\
\hline Total & 73,159 & 43 & & & \\
\hline
\end{tabular}

Based on Table 4.7 method variable had sig value 0,000 . If compare with $5 \%$, value $<0,05$ so $\mathrm{H} 0$ was rejected, meaning that there is effect learning method towards cooperative teaching by controlling pre-test variable. 
Table 4.8. Output comparison of ability to think statistically

\section{Treatment}

Dependent Variable: Postest Teaching

\begin{tabular}{|l|r|r|r|r|}
\hline Treatment & Mean & \multirow{2}{*}{\begin{tabular}{c} 
Std. \\
\cline { 3 - 5 }
\end{tabular}} & & \multicolumn{2}{|c|}{$95 \%$ Confidence Interval } \\
\hline JIGSAW & & Error & Lower Bound & Upper Bound \\
teaching & $8,889^{\mathrm{a}}$ &, 233 & 8,419 & 9,359 \\
NHT teaching & $7,702^{\mathrm{a}}$ &, 233 & 7,232 & 8,172 \\
\hline
\end{tabular}

a. Covariates appearing in the model are evaluated at the following values: Pretest Pembelajaran $=$ 6,9091 .

Posttest comparison average on both methods can be seen on output Table 4.8 showing average posttest score of cooperative teaching on the class given JIGSAW was 8,889 , while the given NHT was 7,702. It can be shown that the class given jigsaw had higher average score than the class given NHT. The difference of both averages was 8,889 . It proved that JIGSAW method was good at increasing students cooperative teaching.

Result of comparative Jigsaw and NHT on the Pre test and Post test by using t-test paired. Hypothesis used was:

Hypothesis 1

H0 : there is no difference JIGSAW Pre Test and Posttest on cooperative teaching.

H1 : there is difference JIGSAW Pre Test and Posttest on cooperative teaching.

Hypothesis 2

H0 : there is no difference NHT Pre Test and Post-test on cooperative teaching.

H1: there is difference NHT Pre Test and Post-test $\mathrm{NTH}$ on cooperative teaching. Testing will reject $\mathrm{H} 0$ if the sig value $<0,05$. Based on $t$ test, it was gained value sig $=$ 0,000 lower than 0,05. It showed that H0 was rejected and there was difference cooperative teaching on the class given JIGSAW method and NHT on Pre test and post-test in which JIGSAW method average was higher than NHT.

Result of comparison Jigsaw and NHT on Post test score with variable compared at the time of posttest using t-test unpaired with hypothesis:

$\mathrm{H} 0$ : there is no difference of cooperative teaching on the class given JIGSAW and NHT method.

$\mathrm{H} 1$ : there is difference of cooperative teaching on the class given JIGSAW and NHT method.

Testing will reject $\mathrm{HO}$ if the sig value $<0,05$. Testing result with $\mathrm{t}$-test was gained significance value $=0,001$ lower than 0,05 . It showed that $\mathrm{H} 0$ was rejected and there was difference cooperative teaching on the class given JIGSAW method and NHT in which average JIGSAW method was higher, 8,9091.

Some precondition fulfilled at the time using control variable (covariate) were normality, variance homogeneity linier correlation between covariate variable (pre-test) with dependant variable (post-test), variance homogeneity slope regression, free covariate variable (pre-test) with treatment (method).

To know whether pre-test and post-test data of JIGSAW and NHT method on teaching cooperative in normal distribution was tested normality using Kolmogorov-Smirnov test with the result of jigsaw pretest and post test as well as a NHT pretest and post test $0,624,0,087,0.763$ and 0,176 in which each variable on JIGSAW and NHT method had sig value Kolmogorov-Smirnov pre- test and post-test > 0,05 so normality condition has been fulfilled.

Homogeneity test is used to know whether data on JIGSAW and NHT method had homogeneous ability (homogenous). Method used was Levene's Test of Equality of Errors Variances. Based on table 4.3. was gained a result that the three dependant variable, cooperative teaching, had sig value of Levene's Test $>0,05$ showing that variance of the variable was homogenous.

On ANCOVA involved control variable, so covariate variable can be seen from linier correlation with dependant variable. To know there was linier correlation or not can be seen from significant value of covariate variable (pre-test) with ANCOVA output. If sig value $<0,05$ it proved that there was linier correlation between covariate variable (pretest) with dependant (post-test). This research had only 1 variable to be tested besides normality and homogeneity of cooperative teaching. Summary result was presented in table 4.4. which showed condition linier relationship on pre-test covariate variable towards post-test dependant variable. Cooperative teaching was fulfilled with sig value $<0,05$. It means pre-test variable on each purpose was good to choose as control variable.

To test whether slope regression variance had homogenous variance can be seen from the absence of interaction between free variable (method) with covariate variable (pretest if sig interaction $>0,05$. Testing result of slope regression can be seen in table 4.5 stating there is no interaction on each free variable method with Post-Test covariate variable of cooperative teaching with sig value 0,592 . Therefore, free test condition as covariate variable was fulfilled.

To prove testing correlation does not have any correlation indicated that both variable does not have any correlation and free to each other indicated by sig value $>0,05$. Table 4.6 showed significance correlation 0,574 meaning there is no correlation between covariate variable and free variable.

\section{Testing Hypothesis on the Effect of Teaching} Method Towards Cooperative Teaching Score. 
Hypothesis used to know the effect towards cooperative teaching was:

$\mathrm{H} 0$ : there is no effect of teaching method towards cooperative teaching by controlling by controlling pre-test variable.

$\mathrm{H} 1$ : there is an effect of teaching method towards cooperative teaching by controlling pre-test variable.

Alternative hypothesis (H1) will be accepted if sig value < 0,05 . Result of ANCOVA test towards cooperative teaching was shown in table 4.7 stating that variable method had sig value 0,000 . If it is compared with $5 \%$ so the value $<0,05$, so $\mathrm{H} 0$ was rejected. It means that there is an effect of teaching method towards cooperative teaching by controlling pre-test variable. Average posttest comparison on both method can be seen in Table 4.8 showing average post-test value of cooperative teaching to the class given JIGSAW method was 8,889. Meanwhile, the class given NHT method was 7,702. It can be said that the class given JIGSAW method was higher average than class given NHT method. Big difference of both averages was 8,889. It showed that JIGSAW method was good to increase student cooperative teaching.

\section{Comparative Result of Jigsaw and NHT Teaching on Pre test and Post test Score. Test Used was t-test paired.}

Hypothesis used was:

Hypothesis 1

H0 : there is no difference in Pre Test and Posttest JIGSAW on cooperative teaching

$\mathrm{H} 1$ : there is difference in JIGSAW Pre Test and Posttest on cooperative teaching

Hypothesis 2

H0 : there is no difference in NHT Pre Test and Posttest on cooperative teaching

$\mathrm{H} 1$ : there is difference in NHT Pre

Test and Posttest on cooperative teaching

Testing will reject $\mathrm{H} 0$ if sig value $<0,05$. Based on testing result with t test was gained sig value $=0,000$ which was lower than 0,05 . It showed that $\mathrm{H} 0$ was rejected and there was difference on comparative teaching to the class given JIGSAW and NHT teaching method to the Pre test and posttest score in which average of JIGSAW method was higher than NTH.

Comparative result of Jigsaw and NHT to Post test score on variable compared in post test time. Test used was t- test unpaired. Hypothesis used was

$\mathrm{HO}$ : there is no difference cooperative teaching to the class given JIGSAW and NTH teaching method.

$\mathrm{H} 1$ : there is difference cooperative teaching to the class given JIGSAW and NTH teaching method.

Table 4.11. Result of testing comparison of cooperative teaching

\begin{tabular}{|c|c|c|c|c|}
\hline Method & Note & Average & Sig t-test & Notes \\
\hline \multirow{2}{*}{ Jigsaw } & Pre-Test & 7,0000 & \multirow{2}{*}{0,000} & \multirow{2}{*}{ Any difference } \\
\hline & Pos-Test & 8,9091 & & \\
\hline NHT & Pre-Test & 6,8182 & 0,000 & Any difference \\
\hline
\end{tabular}

Testing will reject $\mathrm{H} 0$ if sig value $<0,05$. Testing result using $\mathrm{t}$ test on table 4.11 was gained sig value $=0,001$ lower than 0,05 . It showed that $\mathrm{H} 0$ was rejected and there is difference cooperative teaching to the class given JIGSAW and NHT teaching method in which JIGSAW method average was higher ,that is, 8,9091.

\section{CONCLUSION}

Based on result of ANACOVA test can be concluded that NHT and Jigsaw teaching method showed significant effect on $\alpha 0.05$ towards learning outcome of cognitive domain of the students. Average value of the class given JIGSAW method was 8.889 , while the class given NHT method was 7,702. It was seen that the class given JIGSAW teaching method had higher average than the class given NHT method. The higher average showed that JIGSAW method was better in increasing student cooperative teaching.
Observation result of cognitive study domain shown that NHT teaching method informed percentage result was higher than jigsaw teaching method for cooperation in the group.

\section{Suggestion}

The further research can be done with another cooperative teaching so that there is series chain to see the progress gained. 
[5] Miftahul Huda. (2012). Coorperative Learning: Metode, Teknik, Struktur dan Model Terapan. Yogyakarta : Pustaka Belajar

[1] Arikunto, Suharismi (2002). Prosedur Penelitian, Suatu Pendekatan Praktek. Rineka Cipta. Jakarta

[2] Johnson DW \& Johnson, R, T (1991) Learning Together and Alone. Allin and Bacon : Massa Chussetts diunduh dari http://ainamulyana.blogspot.com/2012/02/mod el-pembelajaran-kooperatif-tipe.html pada 8 maret 2018 pukul 20.42

[3] Imam mudofir (2013). Pengaruh strategi pembelajaran dan Modalitas belajar terhadap hasil belajar berbicara bahasa Inggris. Malang: unpublished disertation

[4] D. W., \& Johnson, R. (1989). Cooperation and competition: Theory and research. Edina, MN: Interaction Book Company.

[6] Sukardi, 2004, Metodologi Penelitian Pendidikan: Kompetensi dan Praktiknya, Jakarta: Bumi Aksara.

[7] Santoso, Singgih. (2004). Mengatasi Berbagai Masalah Statistik dengan SPSS Versi 11.5. Jakarta: Elex Media Komputindo.

[8] Trianto, 2009. Mendesain Model Pembelajaran Inovatif-progresif. Jakarta: Kencana Prenada Media Group.

[9] Tran, Van Dat .2012. The effect of Jigsaw Learning on Students' Attitudes in a Vietnamese Higher Education Classroom. International Journal of Higher Education, Vol. 1, No. 2, pp 9-20. diunduh dari http://jurnal.fkip.uns.ac.id/index.php/s2math/ar ticle/view/3519/2453 pada 8 Maret 2018 pukul 11.00 